\title{
Os legisladores do futuro. A afinidade dos projetos políticos de Platão e de Nietzsche*
}

\author{
Yannis Constantinidès**
}

Resumo: o presente texto busca desconstruir o lugar-comum de que Platão é, tão somente, o principal adversário de Nietzsche. Ao analisarmos o percurso da reflexão nietzschiana, veremos que o filósofo, desde sua juventude, e com o progressivo auxílio das ferramentas de análise fisiológica e psicológica, jamais confundiu o platonismo com o homem e legislador político que foi Platão, recebendo dele, inclusive, a influência decisiva no projeto da "grande política". Veremos, paralelamente, que apesar de se considerar como o único herdeiro crítico do filósofo grego, considerado como um criador de novos valores, existem diferenças nos projetos políticos de ambos os filósofos, sobretudo no derradeiro período da reflexão nietzschiana, por meio do pensamento do eterno retorno do mesmo e da leitura do Código de Manu.

Palavras-chave: Nietzsche - Platão - política - recepção crítica - grande política - Código de Manu

Não o melhor, mas o superior! Platão vale mais que a sua filosofia! Nossos instintos são melhores que sua expressão em conceitos. Nosso corpo é mais sábio que nosso espírito! Se Platão parece com esse busto em Nápoles, Nós temos a melhor refutação de todo o Cristianismo! (Nachlass/FP 1884 26[355], KSA 11.156-7).

\footnotetext{
* "Les législateurs de l'avenir (l'affinité des projets politiques de Platon et Nietzsche)". In: Nietzsche. Paris: Éditon de l'Herne, 2005, p. 128-143 (C) Éditons de l'Herne. Tradução de Luís Rubira.

** Professor da Faculdade de Medicina Paris-XI e do Espace Éthique de l'AP/HP. E-mail: constantinides@free.fr.
} 
Desconsiderando a busca constante do efeito que caracteriza a filosofia de Nietzsche, não se retém geralmente, tratando-se de sua relação com Platão, senão sua oposição declarada, cuidadosamente mise en scène, ao platonismo, oposição aparentemente irredutível e definitiva ${ }^{1}$.

É verdade que Nietzsche, essencialmente em sua obra publicada, descreve voluntariamente Platão como um "fanático da moral", desprovido de todo o senso histórico. O prefácio de Para além de bem e mal é, a este respeito, exemplar: Platão ali é apresentado, de modo bastante surpreendente, como líder dos filósofos dogmáticos, na medida em que ele foi o primeiro a afirmar o caráter substancial da verdade e de identificá-la ao "Bem". Nietzsche interpreta assim "a invenção platônica do puro espírito e do Bem em si" como uma verdadeira catástrofe na história da Europa e parece desde então fazer do "combate contra Platão" a tarefa mesma de sua filosofia.

Mas disso até concluir que Platão é o adversário de rigor de Nietzsche, há um abismo que muitos leitores apressados têm alegremente transposto, caindo na armadilha, estendida por Nietzsche nesse Prefácio, da mise em scène do confronto histórico, em escala européia, entre o principal caluniador da vida e o principal afirmador. É fazer pouco caso, portanto, da imensa admiração de Nietzsche por aquele que ele considera como "a mais bela planta (Gewächse) da antiguidade" e ceder ao charme da oposição bem delineada, característica da psicologia rudimentar. Com efeito, se Nietzsche se mostra mais de uma vez muito crítico a respeito do platonismo, ele não tem igual rigor em relação ao homem Platão, que "vale mais que a sua filosofia".

Platão esteve, certamente, na origem desse erro de dois mil anos que é o "platonismo", mas defendendo o seu corpo, por assim dizer, pois ele teria sido "corrompido" por Sócrates e sua moral

1 Cf. Nachlass/FP 1870-71 7[156], KSA 7.199: “Minha filosofia: platonismo invertido: quando mais estamos longe do ente verdadeiro, mais puro, mais belo, melhor é. A vida na aparência como alvo". 
plebéia - moral que lhe seria, em realidade, fundamentalmente estranha (JGB/BM 190, KSA 5.111-3). Para encontrar o verdadeiro Platão, é preciso "tentar caracterizar Platão sem Sócrates" (Nachlass/FP 1875 6[18], KSA 8.104-5), remover essa carga socrática que recobre sua filosofia e a deforma, como as algas da República recobrem a estátua do deus marinho Glauco. Por trás de um socratismo de fachada se dissimularia, assim, o verdadeiro platonismo, o platonismo político.

Abandonando, com efeito, não sem certa desenvoltura, o idealismo platônico e essa moral própria a Sócrates, Nietzsche coloca repentina e resolutamente o acento sobre a dimensão política da filosofia platônica, durante muito tempo negligenciada - por culpa dos neo-"platônicos" particularmente - e única, verdadeiramente, conforme à natureza aristocrática de Platão. O "teórico das Idéias" se eclipsa, portanto, para deixar lugar ao "ativista político"2.

Aos olhos de Nietzsche, assim, Platão é "principalmente" um reformador político, um "legislador do futuro" (Nachlass/FP 1884 26, [407], KSA 11258-9 (fragmento intitulado "O legislador do futuro")); e se ele dá testemunho, desde suas obras de juventude, de sua admiração pelo Estado ideal deste último, é porque o verdadeiro filósofo é, para ele, um legislador, um criador de valores que se designa a tarefa essencial de elevar o homem. Ao convocar Platão em seus textos políticos, Nietzsche se refere, portanto, ao projeto platônico da reforma da cidade: é o sangue do Platão legislador, sem dúvida, que circula em suas veias ${ }^{3}$.

Como conciliar, todavia, a sua condenação do platonismo como fanatismo moral e a admiração extrema que ele mostra pelo projeto político platônico, apesar de sua não-realização? Na realidade, a

2 Cf. Introduction à l'étude des dialogues de Platon. Trad. Olivier Sedeyn. Paris: Éditon de l'éclat, 1991, p.7 (esta citação foi retirada de um curso de Nietzsche sobre Platão na Basiléia, datando do inverno de 1871-1872).

3 Nietzsche afirma que o sangue de Platão circula em suas veias em um fragmento póstumo de A gaia ciência (Nachlass/FP 1881, 12 [52], KSA 9.585). 
denúncia nietzschiana do "platonismo" aponta para a recuperação de Platão pelo cristianismo, para a "vulgarização" de sua filosofia por leitores pouco escrupulosos como Santo Agostinho. Platão não teria tido, assim, os discípulos que sua doutrina política requeria: aqueles que o reivindicaram não possuíam nobreza, não estavam à altura de suas exigências. Esta falsificação inicial do platonismo autêntico explicaria o tenaz "infortúnio" que impediu a edificação do Estado platônico:

Platão defende a necessidade de fundação de um Estado inteiramente novo, para não fazer depender o nascimento do filósofo da irracionalidade dos pais (...). Ora, Platão teve um estranho infortúnio na história: logo que fez surgir uma construção para o essencial, conforme suas proposições, esta não foi sempre, se olhamos de perto, senão o filho de um monstro, um indigno aborto: como o foi o Estado teocrático medieval, comparado com a dominação que ele sonhava dos "filhos de deus" (SE/CoExt III 8, KSA 1.411-27).

Devemos, portanto, deduzir que seu projeto político era irrealizável, que ele era "utópico"? Em um belo texto de Aurora, intitulado "O princípio mau", Nietzsche se insurge contra esta interpretação tradicional e, mais geralmente, contra a propensão superficial de negar a possibilidade daquilo que não pode, até aqui, ser realizado:

Platão descreveu magnificamente como o pensador filosófico deve ser considerado, em toda sociedade existente, o modelo da perversidade: pois, como crítico de todos os costumes, ele é o oposto do homem moral, e, quando não chega a tornar-se o legislador de novos costumes, fica na memória dos homens como o "princípio mau". Podemos imaginar, com isso, que papel teve na fama de Platão a cidade de Atenas, liberal e sedenta de novidades: surpreende que ele - que tinha no corpo o "impulso político", como ele próprio diz - fizesse três tentativas na Sicília, onde parecia então organizar-se um estado mediterrâneo pan-helênico? Nele, e com sua ajuda, Platão pensava em fazer para todos os gregos o que Maomé fez depois para 
os árabes: estabelecer os grandes e pequenos usos e, em especial, o modo de vida cotidiano de cada um. Suas ideias eram possíveis, tão certamente como as de Maomé foram possíveis: afinal, ideias bem mais inacreditáveis, as do cristianismo, demonstraram ser possíveis! Alguns acasos menos e alguns outros acasos mais - e o mundo teria vivido a platonização do Sul da Europa; e, supondo que esse estado prosseguisse até hoje, presumivelmente estaríamos venerando em Platão o “princípio bom”. Mas o êxito lhe escapou: e assim ficou-lhe a reputação de fantasia e utopista - os epítetos mais fortes desaparecem junto com a antiga Atenas (M/A 496, KSA 3.291-300. Trad. Paulo César de Souza).

Esta "platonização do Sul da Europa", se ela tivesse tido lugar, teria, no espírito de Nietzsche, permitido impedir a vitória do cristianismo e mudado o destino da Europa, tal como a islamização modificou o da Ásia. Mas para o autor da Genealogia da moral, aquilo que foi possível permanece possível; eis aí porque, se sentindo por sua vez responsável pela evolução total da humanidade e desejando opor um "contra-ideal" ao "platonismo" cristão, ele se coloca como herdeiro do verdadeiro platonismo.

Se, com efeito, olha-se de perto, a "grande política" que Nietzsche reivindica é, claramente, de inspiração platônica. Ela comporta, como o projeto político exposto por Platão notadamente na República e nas Leis, uma dimensão legislativa e educativa e revela a mesma vontade de determinar por milênios o curso da civilização. Nietzsche chegou a reivindicar esta herança no $§ 57$ do Anticristo, por exemplo, ao final de uma leitura aprofundada e constantemente renovada da obra platônica.

Muito cedo e permanentemente confrontado com a "questão platônica", que ele reconhece ser de uma "formidável complexidade", ele se recusa a reduzir o homem Platão à sua filosofia, encontrando-o num nó bem mais amarrado do que aquilo

4 Em uma carta a Paul Deussen de fim de abril - início de maio de 1868. 
que ela fornece para pensar. De fato, se Nietzsche jamais mudou de olhar sobre o caráter determinante, que ele imediatamente percebeu, do projeto platônico de reforma política, ele, contudo, hesitou muito, como mostra sua correspondência, sobre a significação precisa a ser dada à personalidade desse misterioso "idealista", "que conhecia as entradas interditas de todos os santuários" $"$.

O vemos, assim, progressivamente refinar sua compreensão de Platão (colocar em nuance, por exemplo, a tese um pouco maciça de sua "corrupção" por Sócrates) e dispor de todos os recursos de sua psicologia das profundezas para encontrar o verdadeiro Platão, até os antípodas da imagem caricatural ${ }^{6}$ de fanático moral que ele também gosta, outras vezes, de fornecer para fins essencialmente polêmicos.

Nietzsche, leitor de Platão

O Interesse de Nietzsche por Platão é precoce - ele data de seu período na escola de Pforta - e não diminui até o fim de sua vida consciente. Platão foi, assim, o objeto de uma controvérsia e de uma troca de cartas, entre 1867 e 1869, com Paul Deussen, o futuro indianista e autor de uma dissertação inaugural sobre o autor do Eutidemo. Nietzsche não cessa, em suas cartas, de exortar seu amigo à prudência, lembrando-lhe das dificuldades que comporta todo o estudo da evolução do pensamento platônico.

Vê-se, portanto, Nietzsche imediatamente consciente das armadilhas que contêm toda a leitura da obra platônica que subestima o problema psicológico que constitui o próprio Platão. Se este último o intriga tanto, é porque ele é “o início de alguma coisa

5 Nachlass/FP 1879 44[11], KSA 8.612. No § 28 de Para além bem e mal, Nietzsche evoca neste sentido a "misteriosa natureza de esfinge" de Platão.

6 Cf. Nachlass/FP 188710 [112], KSA 12.460-1: "Platão, por exemplo, vem a ser, para mim, uma caricatura".

114 | cadernos Nietzsche 32, 2013 
bastante nova" (PHG/FT 2, KSA 1.809-12). Na Filosofia na época trágica dos gregos, ele parte, assim, da consideração do homem Platão, que ele apresenta como o "primeiro grande híbrido": "até em sua personalidade se mesclam os traços característicos da distância e da serenidade real de Heráclito, da compaixão melancólica do legislador Pitágoras, e da dialética de Sócrates, o perscrutador de almas" (ibidem).

É para desatar esta complexa meada que ele tenta, após um de seus numerosos cursos sobre Platão na Basiléia, compreender "a filosofia de Platão como expressão do homem Platão"7, aplicando, assim, precocemente, a idéia apresentada em Para além de bem e mal, segundo a qual toda a filosofia é a confissão involuntária de seu autor. Neste curso, ele toma a priori o partido de privilegiar as obras políticas de Platão (sua "Introdução aos diálogos particulares", ignorando a ordem cronológica suposta das obras, começando, assim, de maneira significativa pela República e pelas Leis), à custa de obras mais especulativas como o Parmênides ou o Sofista, que não o interessam muito e sobre as quais ele nada diz. Aos seus olhos, com efeito, a teoria das Idéias não possui valor nela mesma, mas é subordinada à atividade da legislação:

É necessário considerar a missão do legislador de Platão como o ponto central do querer platônico. Ele se coloca na linha de Sólon, Licurgo etc. Tudo aquilo que ele faz, ele o faz com este alvo: de outro modo a vida seria para ele detestável. Seu modo de viver mostra que ele queria ser um modelo a ser seguido: ele precisa viver de modo a ser, de mais em mais, conforme ao seu ideal ${ }^{8}$.

É com a visão desta inspiração fundamental que Platão aparece para Nietzsche como mais próximo de Pitágoras que de Sócrates.

7 Introduction à l'étude des dialogues de Platon, op. cit., título do capítulo 2.

8 Ibidem, p. 22. 
Platão seria, assim, essencialmente um reformador político e religioso e a moral socrática um traço secundário de sua filosofia. Nietzsche manterá ao longo de sua obra esta caracterização primeira do homem Platão, associando-o às vezes a Pitágoras, às vezes a Maomé, tanto ela lhe parece sair de si.

Se ele, do mesmo modo, toma lugar em uma linha helênica de filósofos-legisladores, Platão é, todavia, um caso atípico, uma $e x$ ceção na Grécia. Para Nietzsche, que rebatiza de "pré-platônicos" aos "pré-socráticos", lhe convindo o primeiro: Platão representa uma verdadeira reviravolta na história da Grécia; sob a influência da moral socrática, ele torna a colocar radicalmente em causa os instintos gregos mais profundos (como a vontade de dominação e a valorização da injustiça), opondo-se, assim, à cultura de seu século em sua totalidade. Este ataque de uma violência incrível contra os fundamentos mesmos da civilização helênica faz de Platão um extemporâneo, um "semita" (Nachlass/FP 1877 11[294], KSA 11.294) em vez de verdadeiramente grego.

Por meio desta fórmula provocante, Nietzsche procura colocar em evidência o caráter superficial da apreciação tradicional colocada sobre Platão, seguidamente descrito como o representante por excelência de uma Grécia onde a grandeza residiria na invenção da filosofia e da razão. Para ele, a filosofia retirada dos ensinamentos de Sócrates, colocando o anátema sobre os instintos dos gregos autenticamente gregos, foi que significou bem antes o fim do helenismo. Ele é "judeu" ou "semita" de inspiração em sua recusa da vida instintiva e em sua moral - nesta afirmação particular de que a justiça é preferível à injustiça, mesmo se ela é menos vantajosa que esta última.

Mas onde Platão foi buscar esta inspiração, se os traços socráticos são nele acessórios? Em que sentido é ele "judeu"? Nietzsche funda esta asserção, pelo menos surpreendente, sobre a tradição antiga, que relata que Platão viajou ao Egito, onde ele teria encontrado sacerdotes do alto clero. Preocupado em fazer a genealogia da 
filosofia moral de Platão, de seu "egipticismo", ele chega mesmo a examinar, em certos textos, a curiosa possibilidade de que este último tomou conhecimento direto, no Egito, da moral dos Judeus que ali, então, se encontravam ${ }^{10}$. Esta hipótese não tem sentido senão na medida em que podemos assinalar certa afinidade entre as idéias morais de Platão e aquelas do judaísmo. Ora, para Nietzsche, um traço fundamental é comum aos antigos hebreus e a Platão e justifica tal aproximação tipológica: a afirmação da necessidade de se liberar da tirania dos sentidos.

Essa aproximação, evidentemente nutrida por segundas intenções polêmicas, está, todavia, longe de esgotar a complexidade da questão platônica. Com efeito, mesmo se ele desconfia da sensualidade e coloca o corpo sob a dependência da alma, dificilmente pode-se fazer de Platão um asceta ou um desprezador do corpo, sob o risco de confundi-lo com um retardatário como Plotino. O Banquete ou o Fedro refutam freqüentemente, em todo caso, essa via estreita.

A figura de Platão é, portanto, profundamente equívoca: ele é mais "grego" do que pode sugerir sua moral... Observação que vale, sobretudo, para a sua política, que é, segundo Nietzsche, eminentemente representativa da "vontade helênica":

O estado ideal de Platão é de uma sabedoria particular, pois é precisamente nisso que nos impressiona tanto que se revela a mais impetuosa violência natural da vontade helênica. É, em realidade, o modelo de um verdadeiro Estado de pensadores, com uma situação perfeitamente justa da mulher e do trabalho. Mas o erro não retém senão o conceito socrático do Estado de pensadores: o pensamento filosófico não pode construir, ele não pode senão destruir (Nachlass/FP 1870-71 7[17], KSA 7.140).

9 Cf. CD/CI, A "razão" na filosofia, 1, KSA 6.74-5.

10 Cf. Nachlass/FP 1888 14[85], KSA 13.264: "Platão, que talvez tenha freqüentado a escola dos judeus". Nietzsche utiliza esse tema de maneira polêmica no Crepúsculo dos ídolos (CD/ CI, O que devo aos antigos, 2, KSA 6.155-6). 
Assim, essa "grande natureza moral" (Nachlass/FP de Aurora, 1880, 7[266], KSA 9.373) que era Platão possuía, igualmente, um "forte instinto político" (Nachlass/FP 1880 4[286], KSA 9.170). Há, neste fato, uma profunda contradição entre o Platão legislador e o Platão moralista, contradição constitutiva de sua natureza de Esfinge. Em todo o caso, enquanto homem político, Platão não difere em nada dos outros gregos: não somente o instinto agonal, traço distintivo dos helenos, segundo Nietzsche, não lhe é desconhecido, mas ele é nele desmedido.

Em A disputa de Homero, Nietzsche afirma, neste sentido, que é o "excesso de desejo" e um sentido muito agudo da rivalidade que impeliram Platão à se apossar de Homero. $\mathrm{O}$ conjunto de sua obra proviria mesmo deste instinto agonal hipertrofiado, que ele teria tentado em vão dissimular:

Aquilo que, em Platão, por exemplo, é de uma importância estética admirável em seus diálogos, resulta muito mais de uma competição com a arte dos retóricos, aquela dos sofistas, dos dramaturgos de sua época e isso no sentido de poder dizer, enfim: "Vejam, eu posso também fazer isso que meus maiores rivais são capazes; sim, eu posso fazer melhor do que eles. Nenhum Protágoras jamais imaginou mitos mais belos que os meus, nenhum dramaturgo jamais compôs um resultado tão animado, tão cativante quanto o Banquete, nenhum retórico jamais redigiu discursos como aqueles que eu coloquei no Górgias... Ora, eu nego tudo isso em bloco e condeno toda a arte da imitação! É a disputa somente que fez de mim um poeta, um sofista, um retórico!" (CV/CP 5, KSA 1.783-792).

Este instinto agonal dos gregos, identificado no Crepúsculo dos ídolos com a vontade de potência, exprimia-se não somente nas lutas ginásticas e nas disputas oratórias, mas, sobretudo, e de modo evidente, no combate político. Esse sentido agudo da competição fez do grego "o homem político em si” (CV/CP 3, KSA 1.764-782). Segundo Nietzsche, todos os nobres gregos aspiravam a tornarem-se tiranos, a vontade de dominação exclusiva seria mesmo 
proporcional à nobreza do candidato à tirania. Ora, sabe-se que, em sua visão, Platão seria o mais nobre de todos. Portanto, não é indiferente que a pouco conhecida reflexão nietzschiana sobre o Estado grego é concluída com um vibrante elogio ao Estado ideal da República, que representaria a forma mais bem sucedida, a mais perfeita do instinto político grego:

A cidade ideal de Platão surge, segundo suas considerações, como qualquer coisa de evidentemente maior, na qual não acreditam nem mesmo os mais fervorosos de seus admiradores, sem falar da atitude de superioridade de nossos eruditos "historicizantes" quando ele recusam um tão belo fruto da Antiguidade. Uma intuição poética e um pincel vigoroso revelam o verdadeiro fim do Estado, a existência olímpica, a criação sempre renovada e a formação do gênio face à qual todo outro ser não é senão instrumento auxiliar e condição de possibilidade (ibidem).

Esse projeto de cidade futura permite ao próprio Platão de se fazer perdoar seu anti-helenismo: "Platão tinha o direito de ser cego a toda a realidade helênica, depois dessa visão única que seu olhar jogou sobre o ideal helênico" (WB/CoExt IV 7, KSA 1.429510. A propósito da República platônica, eu sublinho).

Se Nietzsche coloca o acento, ao contrário de sua época, sobre a importância fundamental da dimensão política da filosofia platônica, e se ele mostra tanta estima pelo projeto platônico de uma cidade onde tudo é implementado para permitir ao filósofo alcançar um bom desenvolvimento, é porque ele parte, como Platão, de uma reflexão sobre os benefícios que devem sustentar o Estado e a cultura. O estudo do Estado grego está, segundo toda verossimilhança, na origem desta reflexão sobre a educação, que Nietzsche considera, na mesma linha que o autor da República, como eminentemente política.

O prefácio intitulado $O$ estado grego anuncia, assim, os eixos centrais do pensamento político de Nietzsche. A influência de Platão dessa maneira sobre a "grande política" é inegável. Este, por 
oposição à "pequena política" nacionalista, se propõe à agir na profundeza, isto é, de primeiramente sobre a educação e a cultura, para poder determinar o curso da civilização. Mas antes de examinar detalhadamente esta filiação, é necessário tentar apresentar uma solução ao enigma platônico: quem era verdadeiramente Platão, este híbrido de moral "judia" e de instinto político grego? É para mostrar esta sutil dialética que Nietzsche se esforça para trazer à luz a sua idiossincrasia.

\section{A idiossincrasia particular de Platão}

Se Nietzsche insiste tanto, em sua obra, sobre a "ideomania de Platão, seu delírio quase religioso pelas formas" (FW/GC 357, KSA.3-597-602) e o descreve voluntariamente como um dogmático, é, antes de tudo, para fins polêmicos: trata-se de mostrar que se o admira mais seguidamente por más razões, por "virtudes" que ele pouco possui, em realidade. Ele passa, assim, por um sábio, um puro racionalista, às vezes mesmo por um humanista! Ora, nada é mais falso psicologicamente, segundo Nietzsche, que esta descrição angélica: "Sobretudo, que ninguém vai acreditar que, se Platão vivesse hoje e tivesse opiniões platônicas, ele seria filósofo - seria um louco religioso" (Nachlass/FP 18806 [247], KSA 9.262). Nietzsche toma maliciosamente, deste modo, o contrapé de todos os lugares comuns, de todas as apreciações tradicionais sobre Platão, dividindo, por exemplo, a eterna oposição com os sofistas em favor destes últimos, em o comparando com sua desvantagem em relação a Homero, aos pré-platônicos, a Tucídides ou a Péricles. Mesmo o estilo dos diálogos, tido comumente como superior, não escapa a este questionamento radical do Platão oficial! (CD/CI, "O que devo aos antigos", idem ).

Esta estratégia de dramatização, bastante corrente em Nietzsche, tem por alvo mostrar que a filosofia de Platão é uma máscara que dissimula o homem Platão. Ao invés de se deter nas aparências, é preciso tentar ver o que se esconde por trás das belas declarações 
em favor da justiça, da temperança e da sabedoria, "aquilo que Platão seria verdadeiramente" (Nachlass/FP 18806 [247], KSA 9.262), "no fundo".

Mas ao dissociar assim Platão do platonismo, e ao afirmar que o homem Platão "vale mais" que sua filosofia, Nietzsche não opõe, arbitrariamente, "seu" Platão ao nosso Platão, aquele que nós herdamos dos neo-platônicos e de Santo Agostinho? Em realidade, essa elucidação da psicologia de Platão, apesar de toda a sua radicalidade, pode se dar o direito de um importante fundamento filológico, pois ela se apóia sobre toda uma tradição antiga (Diógenes Laércio, Epicuro, Tímon de Fliunte, Teopompo de Quíos, etc.), bem menos elogiosa, ao olhar de Platão, que são os historiadores da filosofia. Nietzsche outorga, em particular, uma grande importância aos pequenos fatos, pequenos fatos onde aparece, sem disfarce, sua verdadeira natureza.

Nós o vimos insistir sobre o sentido, particularmente agudo, da rivalidade de Platão. Ora, os autores antigos se comprazem precisamente em sublinhar sua philoneikia, tendo, por exemplo, por uma prova de inveja, seu silêncio eloqüente sobre Demócrito. Diógenes Laércio (III, 34-37) levanta, assim, toda uma lista das inimizades de Platão, inspiradas, segundo ele, por um forte ciúme, ciúme que explica que Platão fez de tudo para se assegurar a exclusividade da promoção do ensinamento de Sócrates, em detrimento de Xenofonte e de outros socráticos.

O primeiro traço característico da idiossincrasia de Platão, tal como a reconstrói Nietzsche a partir destes testemunhos, é, portanto, uma vontade de dominação desmedida, mesmo aos olhos da norma grega. Que Platão tenha tentado por todos os meios dissimular esta aspiração à tirania, denunciando-a por suposto nos outros, não deve a este respeito induzir em erro:

Sob toda a oligarquia se esconde sempre (...) o capricho tirânico; toda oligarquia está sempre a tremer da tensão que cada membro sente para permanecer senhor deste capricho. (Assim era, por exemplo, entre os 
gregos; Platão atesta isso em uma centena de passagens, Platão, que conhecia seus iguais - $e$ a si mesmo...) (GM/GM III 18, KSA 5.382-4. Tradução de Paulo César Souza).

Conforme Nietzsche, não é, como ingenuamente acreditamos, a vontade desinteressada em ajudar ao Estado ameaçado pela incompetência dos homens no poder que seria compelida a tomar tão violentamente à cidade ateniense de Péricles, isto é, à conspirar contra sua parte, mas antes este apetite de dominação exclusiva:

Recusa de reconhecer o valor de um outro tipo.

(É preciso considerar Platão: ele nega toda outra grandeza! Homero, os artistas plásticos, a prosa, Péricles - e, para suportar Sócrates, ele o transforma! (Nachlass/FP 1883 8[15], KSA 9.386-7).

Nós estamos, aqui, no lado oposto da "sabedoria" e da "temperança”, tão constantemente elogiadas por Platão. Em realidade, se ele coloca tanto o acento sobre a importância dessas virtudes, é porque estava totalmente delas desprovido... A tal ponto que lhe é permitido se perguntar se o personagem fictício, mas tão incomparavelmente vivo, de Cálicles, não é, em certa medida, uma representação fiel do jovem Platão, e se ele não exprime abertamente inaudíveis reticências do verdadeiro Platão da moral socrática, da imitação de si e da renúncia à vontade de expansão.

De qualquer modo, é necessário, em todo o caso, terminar com a imagem d'Epinal do "divino" Platão e ver nele, antes, um homem devorado por paixões excessivas (cf. M/A 448, KSA 3.271), tentando desesperadamente atingir o domínio de si. Este é o segundo traço essencial de sua idiossincrasia. Aos olhos de Nietzsche, com efeito, Platão sofria de uma sensualidade exarcebada; a dialética, assim, lhe surgiu como um meio inesperado de disciplinar seus sentidos:

Platão era um homem de grande sensualidade e de uma imaginação exarcebada, o charme do conceito veio a ser tão grande nele que ele, 
involuntariamente, venerou e divinizou o conceito como uma forma ideal. Embriaguês da dialética, como consciência de exercer, graças a ela, uma dominação sobre si - como instrumento da vontade de potência (Nachlass/ FP 1886 2[104], KSA 12.112).

Meio contranatural, por certo, mas a exuberância de seus sentidos era tal que a abstração se revelava paradoxalmente benéfica em seu caso (Nachlass/FP 1886 6[7], KSA 12.236). Uma grande segurança de instinto se exprimia, portanto, nesta escolha involuntária que Platão fez da dialética: ele tinha secretamente reconhecido nela um remédio apropriado para o perigo que representaria, para ele, uma sensualidade tropical. Ele teve a força para se administrar este veneno, que iria ao encontro de seus instintos mais profundos, a fim de alcançar uma certa medida, medida depois disso elogiada e elevada ao nível de preceito moral.

Platão teria, assim, graças ao poder de abstração da dialética, espiritualizado seus instintos, tendo moderado a força bruta, impondo-lhe o desvio pela reflexão consciente. $\mathrm{O}$ idealismo não seria, portanto, nele, uma doença, como em outros filósofos, mas o disfarce de uma sensualidade transbordante:

In summa: todo idealismo filosófico foi, até o presente, alguma coisa como uma doença, quando não foi, como no caso de Platão, a precaução de uma saúde opulenta e perigosa, o temor de sentidos potentes, a sabedoria de um sábio socrático (FW/GC 372, KSA 3.623-4).

A oposição não seria, para ele, no começo, senão uma espécie de astúcia, de balaustrada; é, contudo, pelo encanto dessa oposição que sua filosofia seduziu ${ }^{11}$ os desprezadores do corpo, que sofriam da realidade, mas por fraca vitalidade e não por excesso de

11 Cf. JGB/BM 14, KSA 5.28-9: "a magia do pensamento platônico, que foi um pensamento aristocrático, reside precisamente em sua oposição às evidências sensoriais”. 
sensualidade como Platão. É preciso se preservar de confundir Platão com pálidos imitadores como Plotino ou Santo Agostinho, para quem o desejo de fugir da realidade é o fim e não o meio de autodomínio. Platão, por sua vez, não tem, em todo caso, nada de asceta:

Platão vai mais longe. Ele afirma, com uma inocência possível apenas para um grego, não para um "cristão", que não haveria absolutamente filosofia platônica se não houvesse tão belos jovens em Atenas: a visão deles é que lança a alma do filósofo numa vertigem erótica e não lhe dá repouso até que tenha plantado a semente das coisas elevadas num solo tão belo. Também um estado santo! - Não acreditamos em nossos ouvidos, mesmo que acreditemos em Platão. (...) Nada é menos grego que um eremita tecendo teias de aranha conceituais, amor intellectualis de $i$ [amor intelectual a Deus] ao estilo de Spinoza. Filosofia, à maneira de Platão, seria antes definida como uma competição erótica, como aperfeiçoamento e interiorização da velha ginástica agonal e seus pressupostos... O que foi gerado, enfim, por esse erotismo filosófico de Platão? Uma nova forma artística de ágon helênico, a dialética $(\mathrm{CD} / \mathrm{CI}$, Incursões de um extemporâneo, 23, KSA 6.126. Tradução de Paulo César de Souza).

Com efeito, não encontramos em Platão traços do desprezo dos sentidos e do corpo próprios à natureza lógica de Sócrates. Seu busto, conservado no museu Borbonico, em Nápoles, é suficiente, segundo Nietzsche, para provar que o "teórico das idéias" não seria senão uma alma desencarnada.

É, então, necessário explorar a nuance da acusação de "corrupção" dirigida contra Sócrates. Platão foi, na realidade, uma vítima com consentimento: ele soube tirar o melhor proveito deste conluio com seu contrário, o plebeu Sócrates (Nachlass/FP 1884 25[297], KSA 11.87), compreendendo instintivamente a utilidade, para ele, de uma disciplina através da lógica racional. Sócrates foi, neste sentido, vítima de sua própria vítima! Platão retém, por certo, seu ensinamento, mas, antes de tudo, platonizando: 
Platão fez todo o possível para introduzir algo nobre e refinado ao interpretar a palavra do mestre, introduzindo, sobretudo, a si mesmo - ele, o mais temerário dos intérpretes, que tomou de Sócrates inteiro como um tema ou canção popular das ruas, para variá-lo ao infinito e ao possível: isto é, em todas as suas máscaras e multiplicidades próprias (JGB/BM 190, KSA 5.111. Tradução de Paulo César de Souza).

Platão teria a pretensão de aderir a uma moral na qual ele não poderia, de fator, acreditar ${ }^{12}$, no sentido de satisfazer sua vontade de potência. O terceiro traço distintivo de sua idiossincrasia é, desse modo, a duplicidade. Segundo Nietzsche, Platão teria "voluntariamente vendado os olhos"13 quando ele avalia por sua conta a moral socrática. É preciso, portanto, ainda, distinguir entre a imagem que ele buscava dar dele e aquilo que realmente ele era, no fundo:

No fundo, como artista que era, Platão preferiu o parecer ao ser: e, portanto, a mentira, a invenção à verdade, $o$ irreal ao existente, - mas ele estava tão persuadido do valor da aparência que ele lhe vinculou todos os atributos "ser", "causalidade" e "bondade", verdade, em suma, tudo isso ao qual se vincula valor (Nachlass/FP 1886 7[2], KSA 12.251-2).

Platão seria, segundo toda verossimilhança, um comediante da virtude: sua adesão à moral socrática comporta uma grande parte de afetação, de fanfarrice. Os inimigos de Platão - um princípio importante da psicologia nietzschiana, estipula que os inimigos de um pensador são sempre mais lúcidos sobre seu cômputo que seus próprios discípulos - como Epicuro ou Timon (Nachlass/FP 1888 14[116], KSA 13.292-3), o amigo de Pyrrohm e autor de Sátiras contra os filósofos dogmáticos, nisto não se enganaram. Eles não foram logrados com esta comédia platônica da virtude; eles sabiam

12 Cf. Nachlass/FP 188534 [179], KSA 11.481e 34 [195], KSA 11.486-7.

13 Cf. Ibidem, 38[13], KSA 11.611-3. 
que ela servia para dissimular - muito desajeitadamente, pensando bem - a aspiração à tirania:

Como podem ser maldosos os filósofos! Não conheço nada mais venenoso do que a piada que Epicuro fez à custa de Platão e dos platônicos: chamou-os de dionysiokolakes. Isto significa, literalmente e em primeiro lugar, "aduladores de Dionísio", ou seja, clientes de tiranos e bajuladores servis; além de tudo quer dizer, porém, que "são todos atores, nada neles é autentico" (pois dionysokolax era uma denominação popular para ator). E neste outro sentido está realmente a malícia que Epicuro lançou contra Platão: aborrecia-lhe o modo grandioso, a mise-en-scène em que Platão e seus discípulos eram entendidos - e de que Epicuro nada entendia! (JGB/ BM 7, KSA 5.21. Tradução de Paulo César de Souza) ${ }^{14}$.

A aparência, a mentira, seriam, assim, constitutivas do homem Platão, reformador político antes de tudo. A virtude não é para ele senão um meio de alcançar a soberania; ela é subordinada ao seu projeto político: estabelecimento de um Estado que não é, em seu espírito, somente, um "ideal", "em palavras", como ele o pretende, por astúcia, na República, mas possivelmente, realizável, pois que ele já teria existido no passado, caso acreditemos no Timeu.

Os projetos políticos de Platão e de Nietzsche

Nietzsche considera, com efeito, Platão como o único verdadeiro precursor de sua "grande política" e sabe de sua vontade de ter sido o primeiro a tentar uma "reforma do mundo" (Nachlass/FP 14[29], KSA 7.387-8). Conferindo à política a tarefa de decidir pelos milênios do curso da civilização, ele deu-lhe um profundo significado, aos antípodas da política com uma curta visão das nações.

14 Ver também Nachlass/FP 1888 14[129], KSA 13.310-2.

126 | cadernos Nietzsche 32, 2013 
No importante esboço do "Tractatus politicus", que nunca saiu do papel, Nietzsche o apresenta como principal representante da "política da virtude", esta política maquiavélica que não ousa dizer seu nome:

Este tratado (...) trata da política da virtude: ele supõe um ideal desta política, que descreve como deveria ter sido, caso fosse possível algo ser perfeito nesta terra. Ora, nenhum filósofo colocará em dúvida o que constitui o tipo de perfeição na política: a saber, o maquiavelismo. Mas o maquiavelismo puro, sem mistura, cru, verde, com toda a sua força, toda a sua rudez é sobre-humano, divino, transcendente, nunca alcançado pelo homem, somente examinado superficialmente... Nesta espécie mais estreita da política da virtude, parece que nunca foi possível alcançar o ideal. Platão também só conseguiu um exame superficial ${ }^{15}$.

Como mostra na referência a Platão, único filósofo-legislador a ser citado neste texto, Nietzsche inscreve sua própria política na filiação do projeto platônico da cidade ideal. Mas não se trata de uma simples retomada: para levar a termo este projeto abortado, Nietzsche acha necessário renunciar a esta postura virtuosa, que o enfraquece consideravelmente. De fato, é interessante se demorar primeiro sobre a afinidade de seus projetos políticos para depois salientar os limites, indicados pelo próprio Nietzsche, desta aproximação.

Para Platão, assim como para Nietzsche, o legislador do futuro pode ser tanto um médico como um educador: sua tarefa principal é de elevar a planta ou o animal homem ${ }^{16}$. Nossos dois médicos-filósofos partem, de fato, de um diagnóstico pessimista: sua época lhes parece decadente em relação à épocas mais antigas. Eles têm

15 Nachlass/FP 1887-8811[54], KSA 13,25-7 (* em francês no texto; a citação provém de uma carta de 5 de setembro de 1772 do abade Galiani, dito "Macchiavellino").

16 A metáfora vegetal e animal, aplicada à elevação do homem, é comum aos dois autores. Ela é desenvolvida por Platão na passagem da República sobre o "natural filósofo" (VI, 491 d-e), por exemplo. Nietzsche, de sua parte, utiliza freqüentemente, para sublinhar a naturalidade do homem. 
um sentimento de desgosto pelos seus contemporâneos e pelo seu Estado, o qual, segundo eles, representa uma ameaça para a verdadeira cultura. Se eles se declaram a uma só voz "apolíticos", é em referência à política de sua época, uma política tímida. Na realidade, o pensamento deles é político num sentido mais profundo, sendo que engloba uma dimensão educativa e legislativa e que pretende remediar ao estado de saúde, considerado preocupante, da humanidade como um todo.

Aos olhos deles, toda grande civilização tem como condição de possibilidade a hierarquia e a seleção. Eles não acreditam de forma alguma na igualdade natural dos homens. Para Platão, os homens são feitos de diferentes ligas, a origem destas ligas, traduz seu valor natural. Já Nietzsche, ficava de sobreaviso, desde o prefácio sobre "O Estado grego", contra as terríveis conseqüências da doutrina moderna dos direitos iguais para todos, que não somente não instaura realmente a igualdade, mas compromete toda a hierarquia futura, dando fim à "inocência escrava" (cf. CV/CP 3, idem).

É a ilegalidade natural que torna necessária uma "construção piramidal" do Estado e da sociedade cuja base é composta de medíocres. Platão e Nietzsche pensam que os medíocres, seres inferiores em valor, têm a função de servir o todo, enquanto engrenagem. Estes artesãos e trabalhadores manuais, retomando os termos da tripartição funcional da República, devem se encarregar das tarefas mais ingratas a fim de possibilitar aos filósofos naturais o benefício do lazer necessário para uma longa formação espiritual.

Segundo Platão, é “justo" que esta casta inferior seja totalmente dedicada ao bem estar da classe superior. Nietzsche que retoma esta definição platônica de "justiça", no Crepúsculo dos ídolos, acrescenta que esta submissão possibilita aos medíocres de justificar sua existência. $\mathrm{O}$ "radicalismo aristocrático"17 de Platão

17 Esta expressão, proposta por Georg Brandes para caracterizar a filosofia nietzschiana pode, sem sombra de dúvida, ser aplicada a Platão. 
e de Nietzsche vem acompanhado, assim, de um grande desprezo pelos homens medíocres capazes somente de virtudes ou vícios medíocres. É o que se destaca na célebre passagem da República sobre a "corrupção" do natural filósofo:

(...) nós podemos afirmar, da mesma maneira, que as almas mais naturalmente dotadas, elas também, quando se depararem com uma pedagogia ruim, se tornarão excepcionalmente ruins? Ou você acredita que as grandes injustiças e a maldade sem mistura provêm de um medíocre natural, e não de um petulante natural cuja alimentação o leva a sua perda? E você acredita que um natural sem força possa ser a causa de grandes coisas para o bem e para o mal? ${ }^{18}$

Nietzsche observa igualmente que o filósofo é uma "planta rara" (Nachlass/FP 188426 [452], KSA 11.271) e que devemos lhe proporcionar as melhores condições de crescimento, o que supõe segundo ele, o restabelecimento da escravidão. De fato, o estudo do Estado grego conduziu a esta dura conclusão que "a escravidão pertence à essência de uma civilização" ciplina e o aprimoramento (Zucht und Züchtung) dos filósofos que virão - justifica os meios, mesmo extremos, colocados em prática. Mas isto, nada mais é do que retomar uma exigência de Platão, que evidentemente se apóia na realidade da escravidão da sua época.

A dureza desta exigência política não pode senão agredir o leitor de hoje, acostumado a rejeitar a priori toda forma de escravidão. Para Nietzsche, entretanto, todo o criador de valores deve ser duro, a moleza ou a piedade são entraves na atividade da legislação. Isto não quer dizer que o legislador está livre para satisfazer autoritariamente seus caprichos ou para ceder à crueldade.

18 La République, VI, 491 e (La République. Trad. P. Pachet. Paris: Gallimard, 1993).

19 CV/CP idem. Cf. FW/GC 377, KSA 3.628-31. 
Na realidade, a dureza aqui requisitada é aquela do médico, forçado, nos casos extremos, a cortar um membro doente para salvar a vida de seu paciente. Assim, o legislador-médico pode ser levado, pela inquietação da saúde do corpo social, a tomar medidas radicais: se o Ateniense das Leis se declara pronto para recorrer à teoria da raça pura $^{20}$, é somente com o objetivo de curar a sociedade. A fim de mostrar a necessidade de tal "purificação social", Platão, sempre recorrendo à metáfora animal, dá o exemplo de uma tropa, "cuja natureza e uma criação de péssima qualidade a corromperam", mal este que remediamos através de "uma purificação baseada na seleção" antes mesmo de atingir os animais ainda saudáveis. O Ateniense reconhece também que este tipo de remédio é muito difícil de ser aplicado, mas ele estabelece, contudo, a todos os fins úteis que:

O melhor método é sempre o mais doloroso, como todas as medicações deste tipo, já que ele recorre à sentença penal para socorrer o culpado ao qual se acrescenta como última penalidade, a morte ou ser banido. Pois aqueles que cometeram faltas graves, àqueles que são incuráveis e que representam um grande mal à cidade, é comum livrar-se deles ${ }^{21}$.

Nietzsche acredita, também, nos benefícios da teoria da raça pura e na necessidade médica de uma seleção artificial calcado no modelo de seleção natural, ou seja, sem piedade a todos aqueles que são profundamente doentes e em declínio. Trata-se de cortar a vivo no interesse superior da sociedade: "Deve-se amputar o membros doentes: moral primeira da sociedade" (Nachlass/FP 1888 15[13], KSA 13.412-5). Cultivando o paradoxo, Nietzsche sempre apresenta esta terapia radical como mais filantrópica que

20 Cf. Lois, V, 735 b -736 c.

21 Ibidem, 735 d-e (tradução de A. Castel-Bouchouchi).

130 | cadernos Nietzsche 32, 2013 
a medicina que se esforça a todo custo em prolongar a vida dos doentes, sem levar em conta o valor da vida assim conservada. A obstinação terapêutica é, de fato, contrária à moral que deveria ser aquela do médico:

Moral para uso dos médicos. O doente é um parasita da sociedade. Num certo estado, é indecente viver mais tempo. Prosseguir vegetando em covarde dependência de médicos e tratamentos, depois que o sentido da vida, o direito à vida foi embora, deveria acarretar um profundo desprezo na sociedade. Os médicos, por sua vez, deveriam ser os intermediários desse desprezo - não apresentando receitas, mas a cada dia uma dose de nojo a seus pacientes... Criar uma nova responsabilidade, a do médico, para todos os casos em que o supremo interesse pela vida, da vida ascendente, exige a mais implacável supressão e rejeição da vida que degenera - por exemplo, para os casos do direito à procriação, do direito de nascer, do direito de viver... (CD/CI, Incursões de um extemporâneo, 36, KSA 6.134-6).

A familiaridade deste texto com o projeto de regulamentação da medicina proposto por Platão na República, onde o médico tem o direito de praticar a eutanásia em nome de uma exigente concepção de saúde, é extremamente assustadora:

- Sócrates: Então você instituirá também através da lei uma arte médica, tal como nós a tínhamos descrito, ao lado da arte de julgar assim definida, na cidade? Artes estas que curaram seus cidadãos bem dotados de corpo e de alma entre aqueles que não o são, eles deixarão morrer todos aqueles cujo corpo está doente; e farão eles mesmos morrer aqueles cuja alma tem uma má natureza e que são incuráveis?

— Glauco: É, sem dúvida, o que apareceu como o melhor, tanto para os que sofrem como para a cidade ${ }^{22}$.

22 La République, III, 409 c - 410 a (op. cit.). 
A purificação da sociedade tem, assim, por finalidade, permitir que se apóie sobre uma base ainda medíocre, mas ao menos sã. Entretanto, a atividade legisladora não para por aí: para impedir que a corrupção não se alastre novamente no corpo social, é necessário um controle estrito dos casamentos e da procriação. Nietzsche insiste ainda, seguindo Platão, na necessidade de uma seleção sexual, ou seja, de efetivar os casamentos em função da descendência prevista, com o objetivo de impedir elementos arbitrários como a paixão ou o amor para decidir as uniões (cf. CD/CI, idem, 29, KSA 6.140-2).

Conhece-se, de fato, a verdadeira ordem das castas exposta na Republica, com a interdição, por exemplo, dos guardiões de se unirem a mulheres de uma escala inferior. É importante acrescentar a esta interdição a prática autoritária do casamento entre os melhores guardiões com o objetivo de se obter o melhor progenitor possível. Platão justifica esta prática como inadmissível para a sociedade - a tal ponto que se deve escondê-la a qualquer custo, dos próprios guardiões! - mais uma vez em analogia ao mundo animal (pássaros, cães, cavalos de raça), onde os melhores se unem naturalmente aos melhores:

— Sócrates: é necessário (...) que os melhores homens se unam às melhores mulheres o mais freqüentemente possível, e os mais medíocres às mulheres mais medíocres, neste caso o menos freqüente possível; alimentar os descendentes dos primeiros e não os dos outros, caso queiramos uma nação de melhor qualidade; é importante ainda, que tudo isto passe despercebido, salvo dos dirigentes eles mesmos, caso queira-se, em contrapartida, que a tropa de guardiões se mantenha isenta das discórdias internas ${ }^{23}$.

Não contente em arranjar desta forma os casamentos "sagrados" entre os melhores guardiões, o legislador platônico pretende

23 République, V, 459, d-e (op. cit.). 
também o direito de controlar a procriação. Temeroso por exemplo de uma possível transmissão de uma predisposição mórbida, ele pode intervir como Esculápio - "Um Esculápio político", retomando o profundo comentário de Glauco - para impedir a procriação ${ }^{24}$. Segundo Nietzsche, tal medida de prevenção é essencial para preservar a sociedade, pois é muito perigoso nestes casos deixar acontecer:

Nos casos onde a criança seria um crime: doentes crônicos e neurastênicos de terceiro grau, onde opor um veto ao instinto sexual equivaleria a um voto de piedade (- este instinto desperta, seguidamente, nos menos favorecidos, uma repugnante excitabilidade), é preciso exigir que a procriação seja impedida. A sociedade desconhece as exigências urgentes e fundamentais para tal. Aqui, não basta o desprezo, a declaração de indignidade social, para manter presa uma vil debilidade de caráter (...). Colocar uma criança no mundo, quando já não se tem o direito de estar nele, é pior que tomar uma vida. O sifilítico que põe um filho no mundo é o causador de uma série de vidas perdidas, ele cria um argumento contra a vida, ele é um pessimista em atos: na verdade, o valor da vida para ele é reduzido e incerto $-{ }^{25}$.

Tendo que decidir sobre o conjunto de atos importantes da vida cotidiana, o legislador do futuro, conforme a concepção de Platão e de Nietzsche, não pode ser senão um educador. Enquanto médico, o vimos cassar a doença por toda parte, remediá-la, preveni-la, enfim, concluir uma tarefa acima de tudo negativa. Enquanto educador, sua obra é essencialmente positiva: trata-se de garantir as melhores condições de vida aos naturais filósofos devidamente selecionados de modo prévio.

Considerando-se que estes seres de exceção são também os mais facilmente corrompidos, uma tal paidéia, é o contrário de uma

24 Cf. Ibidem, III, 407 d-e.

25 Nachlass/FP 1888 15[3], KSA 13.401, ver também ibidem, 23[1], KSA 13.599-600. 
educação negativa; ela supõe por parte do educador uma solicitação inquieta desde a primeira infância, até mesmo antes do nascimento $^{26}$. Os cuidados com o corpo constituem evidentemente, o ponto de partida desta educação:

O Ateniense: (...) educar como convém é, fundamental, ser capaz de dar aos corpos e às almas o máximo possível de beleza e de excelência (...)

Ora, para que os corpos sejam os mais belos possíveis, é preciso (...) que eles cresçam da forma mais conveniente possível desde a primeira infância ${ }^{27}$.

Nietzsche, que explicitamente se inspira em Platão sob este ponto essencial ${ }^{28}$, considera também que toda verdadeira educação começa pela fisiologia:

É decisivo, para a sina de um povo e da humanidade, que se comece a cultura no lugar certo - não na "alma" (como pensava a funesta superstição dos sacerdotes e semi-sacerdotes): o lugar certo é o corpo, os gestos, a dieta, a fisiologia, o resto é consequência disto...( CD/CI, idem, 47, KSA 6.148-9).

Pode-se objetar que a paideia platônica se propõe precisamente o bem estar da "alma", senão ainda mais, que o do corpo. Se a educação começa efetivamente pela ginástica, ela se aperfeiçoa pela "música", ou seja, por tudo que diz respeito à formação espiritual. Mas isto não quer dizer que Platão considere o desenvolvimento da alma mais importante que o do corpo: o ideal de educação

26 Para o ateniense das Leis, que não ignora que esta estranha medida de risco de passar por ridículo, o exercício físico deve ser prescrito às mulheres grávidas, o feto tendo necessidade de movimento para se desenvolver harmoniosamente (cf. Lois, VII, 789 a - 790 d).

27 Ibidem, 788 c-d (trad. A. Castel-Bouchouchi). Platão parte, aqui também, de uma analogia com o crescimento vegetal e animal.

28 Cf. Nachlass/FP 1884 26 [353], KSA 11.243: "Depressa elevar o corpo: encontra-se bem o pensamento que corresponde. Platão".

134 | cadernos Nietzsche 32, 2013 
é de chegar a um equilíbrio perfeito entre ginástica e música, ou seja, entre dureza e leveza. A completa instrução que Platão preconiza não se restringe à ginástica nem tão pouco à música, mas não vale senão por sua mistura:

Àqueles que recorrem à arte da ginástica sem mistura se tornam mais brutais que o necessário, enquanto àqueles que recorrem à arte das Musas se tornam, ao contrário, mais delicados do que os convém ${ }^{29}$.

Nietzsche também leva em conta esta mistura de dureza e de leveza - que é um dos temas centrais do Zaratustra - como essencial. Contrariamente a uma ideia tenaz particularmente recebida, apoiando-se na pretensa glorificação da "besta loira" na Genealogia da moral, ele não se opõe jamais, de maneira simplista, à força bruta dos "fortes" e à fraqueza dos "fracos". Ele se afirma simplesmente, como Platão antes dele, na espiritualidade excessiva, que leva ao esquecimento do corpo e dos sentidos:

Espiritualização fixada como alvo: assim, a oposição cortada entre o bem e o mal, virtude e vício, é uma disciplina que tende a tornar o homem mestre dele mesmo, uma preparação à espiritualidade - Mas se não há ao mesmo tempo sensualização, o espírito se torna muito magro (Nachlass/FP 1884 26 [398], KSA 11.255).

Nietzsche rejeita assim, espelhado em Platão, toda forma de dominação brutal repousado somente sobre a força, em benefício de um poder espiritual, pelo qual a força é apenas um instrumento. Na Republica, o filósofo-rei se revolta com a forma direta de exercício do poder, se mantém de fato retirado, contentando-se com uma direção espiritual e delegando aos "guardiões" ou guerreiros a responsabilidade da dominação propriamente dita. Nietzsche

29 La République, III, 410 d (op. cit.). 
subscreve totalmente este modo refinado de dominação e recupera, no $§ 57$ do Anticristo, o termo platônico "guardiões", para indicar seu acordo na repartição das funções previstas por Platão para sua Politeia. Esta dominação espiritual daqueles que sabem esperar, resistir às solicitações, é aos olhos de Nietzsche infinitamente superior à vontade grosseira da dominação, como por exemplo, a do tirano. Os verdadeiros "mestres da terra" não são os homens no poder, mas sim os criadores de valores, os legisladores.

Ao invés de compararmos anacronicamente, como muito já se fez, as construções políticas de Platão e de Nietzsche com evoluções contemporâneas como o Estado totalitário ou o Estado nazista, seria então mais justo e mais indicado mostrar a semelhança gritante com o sistema indiano das castas, verdadeiro precursor em matéria de subordinação do poder executivo a uma direção espiritual, àquela dos padres em conjetura. Entretanto, vale lembrar que a ordem de castas que Platão e Nietzsche visam instaurar não é de inspiração ascética - dito de outro modo, não se trata de uma direção puramente espiritual - e que deve ser dirigido, não por padres, mas por filósofos.

Conforme se pode constatar, os projetos políticos de Platão e de Nietzsche são muito próximos, mesmo nos detalhes. Entretanto, é importante indicar, no final desta comparação, os limites, colocados em destaque pelo próprio Nietzsche. Com efeito, ainda que ele tome como sua a concepção platônica de um regime dominado por uma hierarquia espiritual, Nietzsche repreende constantemente Platão de ter uma dupla fraqueza, que se deve sem dúvida imputar a sua máscara moral: o recurso à "nobre mentira", traço característico dos reformadores religiosos e seu "egipticismo", seu gosto pela fixidez, que explica em Platão a ausência de sentido histórico $^{30}$. Ora, a mentira educativa tem por objetivo impor esta ilusão de permanência:

30 Cf. Nachlass/FP 1884 26[393], KSA 11.254: "O sentido histórico: Platão e toda a filosofia não tinham nenhuma idéia". 
Platão julgava indispensável, para educar a primeira geração de cidadãos da sua nova sociedade (no Estado perfeito), recorrer a uma vasta mentira necessária: as crianças devem ser levadas a crer que todos já viveram e sonharam em algum momento embaixo da terra, onde eles foram moldados e formados pelo autor da natureza. Impossível de se insurgir contra este passado! Impossível de se opor a obra dos deuses! Assim o queria uma lei inviolável da natureza: aquele que nasce filósofo tem ouro no seu corpo, aquele que nasce guardião tem somente a prata, o que nasce trabalhador tem o ferro e o bronze. Do mesmo modo, explica Platão, que não é possível misturar estes metais, também não é permitido transgredir e transformar a ordem de castas (Kastenordnung); a crença na aeterna veritas desta ordem é o fundamento da nova educação e, portanto, do novo Estado (HL/CoExt II 10, KSA 1.324).

Se Nietzsche rejeita a crença de Platão das verdades eternas, das formas imutáveis, é porque esta crença, que leva a divinização do Estado, está, segundo ele, na origem do socialismo e do despotismo $^{31}$. Que o fanatismo moral foi para Platão somente uma máscara, uma manobra da sua vontade de potência e não uma determinação essencial, como na visão socialista, pouco importa sob o olhar dos seus efeitos desastrosos. Manchada pela adesão contra natureza de Platão à moral socrática, sua "política de futuro" se revelou definitivamente, mais reativa que positiva:

(...) ele liberou os instintos da polis, do estímulo, do valor militar, da arte, da beleza, dos mistérios, da fé na tradição e nos ancestrais...

- ele foi o sedutor dos nobles, ele mesmo seduzido pelo Routier Sócrates...

- ele negou todas as condições que sozinhas permitem o desabrochar dos "nobres gregos" de boa raça, aplicou a dialética no uso cotidiano,

31 Cf. MA I/HH I 473, KSA 2.307-8 e MA II/HH II, “O andarilho e sua sombra”, 285, KSA 2.679-80. 
conspirou com os tiranos, levou uma política de futuro (trieb ZukungftsPolitik) e mostrou o exemplo do mais perfeito desprendimento do instinto de tudo que é antigo.

Ele é profundo e apaixonado por tudo que é anti-helênico... (Nachlass/ FP 1888 14(94), KSA 13.271-2).

É no dogmatismo de Platão que se faz necessário imputar o fato de que sua política teve efeitos opostos aos que ele prévia, a máscara moral que ele pensou ser boa para revestir, tendo permitido ao cristianismo recuperá-la... Se Nietzsche rompe com esta comédia da virtude, renunciando à nobre mentira e à deformação moral da vontade de potência, é por essencialmente por razões de eficácia política. A "grande política" nietzschiana se opõe, com efeito, a todo endurecimento moral e não dissimula sua crueza ${ }^{32}$.

Entretanto, se Nietzsche sente aversão em vestir a máscara do profeta, artimanha habitual dos reformadores políticos e religiosos, não por isso, se exclui a utilização cínica da religião como um meio de assegurar a coesão da construção piramidal da sociedade:

O filósofo, tal qual o compreendemos, nós, espíritos livres - o homem da responsabilidade mais ampla, que se preocupa com a evolução do homem: este filósofo se utilizará das religiões para sua obra de educação e cultivo, do mesmo modo que se utilizará das condições políticas e econômicas do momento. A influência cultivadora, seletiva, isto é, tanto destrutiva quanto criadora e modeladora que se pode exercer com a ajuda das religiões é sempre múltipla e diversa, conforme o tipo de homens colocados sob seu domínio e proteção. Para os fortes, independentes, preparados e predestinados ao comando, nos quais se encaram a razão e a arte de uma raça dominante, a religião é mais um meio de vencer resistências para dominar: é um laço que une dominadores e

32 Cf. Ibidem, 25[1], KSA 13.637-8. Pode-se, de certo modo, ver no programa político que expõe este texto uma versão crua do projeto platônico.

138 | cadernos Nietzsche 32, 2013 
súditos, e que denuncia e entrega àqueles a consciência destes, o que neles é mais íntimo e oculto, que bem gostaria de se subtrair à obediência; e se algumas naturezas de origem nobre se inclinarem por uma elevada espiritualidade, a uma ida mais refinada espécie de domínio (sobre discípulos eleitos ou irmãos de ordem), a religião pode ser usada inclusive como meio de obter paz frente ao barulho e à fadiga de modos mais grosseiros de governo, e limpeza frente à necessária sujeira de toda política. Assim fizeram os brâmanes, por exemplo: através de uma organização religiosa atribuíram-se ao poder de nomear reis para o povo, mantendo-se e sentindo-se e à margem, como indivíduos de tarefas superiores e supra-reais. Entretanto a religião também fornece, a uma parte dos dominados, orientação e oportunidade de preparar-se para dominar e comandar algum dia: àquelas classes e camadas que sobem lentamente, nas quais não param de crescer, mediante felizes costumes matrimoniais, a força e o prazer da vontade, a vontade de autodomínio - a elas a religião oferece estímulos e tentações suficientes para percorrer o caminho da espiritualidade superior, para colocar à prova os sentimentos da grande superação de si mesmo, do silêncio e da solidão - ascetismo e puritanismo são meios de educação e enobrecimento quase indispensáveis, quando uma raça pretende triunfar de sua origem plebéia e ascender ao domínio futuro. Aos homens ordinários, enfim, o grande número que existe para o serviço e para a utilidade geral, e que apenas assim tem direito a existir, a esses a religião proporciona uma inestimável satisfação com seu estado e seu modo de ser, uma reiterada paz do coração, um enobrecimento da obediência, mais alegria e mais dor em comum com seus iguais, e alguma transfiguração e embelezamento, alguma justificação de toda a cotidianidade, de toda a baixeza, toda a pobreza semi-animal da sua alma (JGB/BM 61, KSA 5.79-81. Trad. Paulo César Souza).

Esta exigência parece entrar em contradição com a vontade, diversas vezes expressada, de se liberar de toda e qualquer religião. É importante não se enganar: somente aqueles que Nietzsche denomina os "espíritos livres" são suficientemente fortes para 
viver sem religião; os outros - todos aqueles que fazem parte da "tropa" não conseguem viver sem religião. A partir deste momento, seu alvo declarado é o de aumentar o fosso que separa os espíritos livres da tropa através da instauração de uma nova religião. Esta religião seletiva, verdadeiro "martelo nas mãos dos homens mais potentes" (Nachlass/FP 1884 27[80], KSA 11.295), nada mais é do que a "doutrina do eterno retorno", que Nietzsche apresenta com prazer como a forma exagerada do niilismo e que ele associa com freqüência a "nova hierarquia" (Neue Rangordnung), que ele se propõe a colocar em ação.

Logo o "filósofo do futuro" de Nietzsche não aprova, diferentemente de Platão, a necessidade de colocar voluntariamente uma venda nos olhos. Ele não se deixa seduzir, como mais de um reformador religioso, por sua própria doutrina, a ponto de se tornar um dogmático ou um fanático. Para além de Platão, que não soube resistir ao charme das verdades eternas e da estabilidade, Nietzsche reencontra fundamentalmente o realismo político de Maquiavel.

Entretanto não se encontra aqui, o último estado da leitura nietzschiana de Platão. Em 1888, tendo tomado conhecimento das Leis de Manu, o código da religião brâmane, Nietzsche logo imagina aproximá-lo do projeto político platônico, fazendo curiosamente, deste código a fonte primeira das ideias de Platão. Retomando a metáfora nietzschiana, seria o sangue de Manu que circularia nas veias de Platão.

“Platão, o bramanista". Uma nova leitura do $\$ 57$ do Anticristo

A leitura do código de Manu ajuda Nietzsche a precisar e afinar uma compreensão da filosofia platônica que ainda hesitava entre o ascetismo aparente e a vontade de dominação subjacente, esclarecendo a natureza real do bramanismo, que doravante surge radicalmente distinta do budismo. Nos seus textos anteriores à primavera de 1888, Nietzsche associava Platão, quase indiferentemente, a 
Buda ou aos Brâmanes, crendo aproximá-lo nos dois casos, de um pensamento político, se apoiando em uma moral ascética e uma vontade de eternizar negando toda a história e todo vir-a-ser. É esta crença na unidade de inspiração do vedismo que explica que Platão seja apresentado no Prefácio de Para além do bem e do mal, como o vetor europeu de uma filosofia dogmática cujo vetor oriental seria a "doutrina de Vedanta".

Antes de ler, tardiamente, as Leis de Manu, Nietzsche via nos brâmanes apenas representantes por excelência da "moralidade dos costumes" (cf. M/A 9 e 96, KSA 3.21-4 e 87-8), os padres ascéticos se isolando do mundo e satisfazendo seu sentimento de potência apenas no campo espiritual. A descoberta deste código em uma tradução francesa ${ }^{33}$ o obriga a renunciar a esta perspectiva tradicional que faz padres brâmanes, niilistas. Na realidade, o caráter afirmador de "uma obra incomparavelmente tão inteligente e soberana" não causa a menor dúvida e rompe com o ascetismo da Bíblia judaico-cristã:

Logo se percebe: ele tem uma verdadeira filosofia atrás de si, em si, não apenas uma malcheirosa judaína de rabinismo e superstição - até ao mais fastidioso psicólogo ele dá algo substancial para morder. Não esquecendo o principal, a diferença básica em relação a toda espécie de Bíblia: com ele as classes nobres, os filósofos e guerreiros, erguem a mão sobre a multidão; valores nobres em toda parte, um sentimento de perfeição, um dizer Sim à vida, um triunfante sentimento de bem-estar consigo e com a vida - o Sol está em todo o livro. - Todas as coisas nas quais o cristianismo verte a sua insondável vulgaridade, a procriação, por exemplo, a mulher, o matrimônio, são aí tratados seriamente, com reverência, com amor e confiança (AC/AC 56, KSA 6.239-44. Tradução de Paulo César Souza).

33 Louis Jacolliot, Les législateurs religieux. Manou-Moïse-Mahomet. Traditions religieuses comparées de lois de Manou, de la Bible, du Coran, du rituel égyptien, du Zend-Avesta des Perses et des traditions finnoises, Paris, Lacroix, 1876. 
Evidentemente cabe, aqui, mostrar o exagero polêmico neste texto, que se serve das Leis de Manu como de uma arma de guerra contra o cristianismo. Não há dúvidas de que Nietzsche nutre uma verdadeira admiração por este código sacerdotal, que ele considera como a mais antiga tentativa de hierarquização da humanidade, de "construção piramidal" da sociedade. Platão, então, não foi o primeiro a tentar uma reforma do mundo: os nobres brâmanes, que aliás estão na origem de toda ordem de castas "arianas", o precederam neste propósito:

Obtive, nestas últimas semanas, um ensinamento capital: Encontrei o Livro da lei de Manu, numa tradução francesa feita na Índia sob o rígido controle dos mais iminentes padres e sábios de lá. Este produto (Erzeugniss) totalmente ariano, um código sacerdotal da moral fundado sobre os Vedas, o sistema de castas e uma antiga tradição - não pessimista, ainda que bem sacerdotal - completa de forma impecável minhas idéias sobre a religião. Eu tenho a impressão, e confesso, de que tudo que possuímos de outro em matéria de grande legislação moral, parece ser apenas uma imitação e uma caricatura: em primeiro lugar o egipticismo: mas Platão me parece, sobre todos os pontos essenciais, ter simplesmente recebido o excelente ensinamento de um Brâmane ${ }^{34}$.

Pode-se de fato, legitimamente, se surpreender de ver o pretenso "semita do instinto" Platão, se inspirar num modelo "ariano". Ele não deveria, antes de tudo, logicamente, reproduzir os modelos semíticos de organização do Estado? Na realidade, nós somos aqui mais uma vez remetidos à complexidade do homem Platão: sua moral é certamente de inspiração "semítica", mas a repartição das funções que ele preconiza para sua cidade ideal é, ao contrário, tipicamente "ariana". Se Nietzsche escolhe, com conhecimento de

34 Carta a Peter Gast de 31 de maio de 1888 (*em francês no texto). 
causa, associá-lo exclusivamente à Manu, é porque ele estima que esta influência "ariana" foi, no seu caso, a mais determinante:

Platão está totalmente no espírito de Manu: iniciou-se no Egito. A moral das castas, o Deus dos Homens Bons, a "alma única e imortal."

- Platão o Brâmanista (Plato der Brahmanist) ${ }^{35}$.

A tripartição platônica da cidade parece, de fato, se inspirar fortemente na hierarquia tradicional das $\operatorname{castas}^{36}$ : ainda que comportando uma casta a menos, ela ressalta a importância de uma direção espiritual do Estado - é a esta diferença, já ressaltada anteriormente, que ela confia este poder espiritual aos filósofos e não aos padres - e prevê, assim, também uma casta intermediária de guerreiros, que cuidam do governo, assim como uma extensa base de medíocres, cuja razão de existir é para servir as castas superiores.

Não é por acaso se o nome de Platão surge espontaneamente sob a pena de Nietzsche, como termo de comparação, quando ele descobre as Leis de Manu: é, de fato, com olhos platônicos que ele lê esta obra, ficando mais tempo nas passagens sobre o casamento (livro III), sobre a autoridade e as prerrogativas dos reis (livro VII), a mistura das castas (livro X), e sobre as disposições previstas para manter a ordem das castas (livro XI), ou seja, sobre o conjunto das disposições que o interessaram no projeto político platônico.

Retornando de Platão à Manu, Nietzsche reencontra Platão principalmente na idéia de uma separação estrita das castas, que o autor do Código de Manu apresenta já em conformidade com a justiça e a ordem natural. Desta forma, nos vemos no direito de pensar

35 Nachlass/FP 1888 14[191], KSA 13.378. Em Homo hierarchius, Louis Dumont também compara a República de Platão com a ordem indiana das castas, apresentando-a como uma versão filosófica desta "gradação religiosa" (Gallimard, 1966, cap. III, p. 92).

36 Esta construção piramidal comporta, como se sabe, quatro castas: os padres brâmanes no topo; uma escala abaixo, a classe guerreira (Kshatryas); mais baixo ainda, os Vaishyas, artesãos ou comerciantes, a base estando constituída pelos Shudras (ou Soudras), servidores ou homens de nada (ver L. Dumont, Homo hierarchius, Op. cit., p. 93 sg.). 
que é a compreensão de Platão como legislador, dissimulando sua política sob uma fantasia moral, que deu disposição a Nietzsche para interpretar as Leis de Manu como uma reflexão política no fundo cínica:

Engana-se supondo aqui (no Código de Manu), uma evolução inconsciente e ingênua, uma maneira de abusar de si mesmo... Não são os fanáticos que são os inventores de tais sistemas elaborados de opressão... Aqui esta a reflexão a mais fria colocada em obra, este mesmo tipo de reflexão [grifo nosso] que tinha um Platão no momento em que imaginou sua "República".

"Quando se quer o fim, é preciso querer os meios" - todos os legisladores sempre estiveram, em seu foro interior, conscientes desta sabedoria de políticos (Nachlass/FP 1988 15[45], KSA 13.439).

A "santa mentira", comum a todos os legisladores, faz evidentemente parte destes meios políticos imorais. Não se pode, porém, deduzir que todos os legisladores se valham: se os meios colocados em prática são por toda à parte os mesmos, os fins perseguidos são obrigatoriamente diferentes. Nietzsche distingue radicalmente, em função dos seus fins, a "moral de l'élevage", que é a de Manu e de Platão, da "moral de dressage" do cristianismo (cf. CD/CI, Os "melhoradores" da humanidade, 2 e 3, KSA 6.99 e 100-1): a primeira visa tornar possível a existência de homens excepcionais graças à instauração de uma hierarquia estrita imitando a natureza, enquanto que a segunda, provinda das camadas mais baixas da sociedade, procura, ao contrário, torná-los doentes, enfraquecê-los.

Isto nos leva ao $\S 57$ do Anticristo onde Nietzsche, partindo do principio do código de Manu, vem detalhar a organização das castas conforme a ordem natural:

Em toda a sociedade sã se distinguem, condicionando um ao outro, três tipos de diferente gravitação fisiológica, dos quais cada um tem sua própria higiene, seu próprio âmbito de trabalho, sua própria espécie de 
mestria e sentimento de perfeição. (...) A casta mais alta - eu a denomino os poucos - tem, sendo ela a perfeita, também as prerrogativas dos poucos: entre elas, a de representar a felicidade, a beleza, a bondade na terra (...). Eles [a mais venerável espécie de homens] não dominam porque querem, mas porque $s \tilde{a} o$, não lhes é dado serem os segundos. - Os segundos: eles são os guardiões do direito, os que cuidam da ordem e da segurança, os guerreiros nobres, sobretudo é o rei, como a mais alta fórmula de guerreiro, juiz e mantenedor da lei. Os segundos são os executivos dos homens mais espirituais, o que eles têm de mais próximo, o que lhes tira o que há de grosseiro no trabalho de dominar - seu séquito, sua mão direita, seus melhores alunos. (...) $\mathrm{O}$ artesanato, o comércio, a agricultura, a ciência, a arte em sua maior parte, a quintessência da atividade profissional, em sua, é compatível tão somente com uma mediania na capacidade e nos anseios: algo assim estaria deslocado entre as exceções, o instinto que lhe é próprio estaria em contradição tanto com o aristocratismo como com o anarquismo.

Mesmo que este texto esteja inscrito no desenvolvimento sobre Manu e não sobre Platão, vale constatar que ele se inspira mais na tripartição funcional da República que na divisão indiana da sociedade (em quatro ${ }^{37}$ castas!), os termos de "guardião" e de "artesãos" remetem, aliás, explicitamente a esta tripartição. Este deslizamento também foi possível pela similaridade tipológica das duas reflexões políticas, mas ela se explica, sobretudo, porque Nietzsche interpreta o Código de Manu com a ajuda de sua elucidação psicológica do caso Platão. Platão lhe serve, assim, enquanto "bramanista", de modelo de inteligibilidade para compreender os brâmanes.

Fazendo do filósofo um legislador, um criador de valores, Nietzsche confere ao velho projeto da "Platonópolis" um alcance do qual

37 Nietzsche não distingue aqui, com efeito, senão três tipos fisiológicos essenciais, e não quatro, reagrupando as duas castas inferiores dos Hindus na categoria platônica dos “artesãos". Algo que não é um desprezo, mas um gesto deliberado, pois Nietzsche conhece perfeitamente o detalhe da hierarquia das Castas (ver CD/CI, idem, KSA 6.100-1). 
não suspeitaram os neo-platônicos. Ele se coloca como herdeiro do verdadeiro Platão, herdeiro crítico, inspirando-se amplamente do projeto político deste primeiro verdadeiro filósofo-legislador do futuro, denunciando a moral que o acompanha.

Neste sentido, mesmo se ele não "inverte" em realidade senão o "platonismo", a relação de Nietzsche com a filosofia platônica permanece ambígua. Como é justo, é ao seu amigo indianista, Paul Deussen, que ele entrega a chave:

- Talvez esse velho Platão seja, em verdade, meu maior adversário? Mas como sou orgulhoso por ter um tal adversário! - ${ }^{38}$

\begin{abstract}
The present text seeks to deconstruct the commonplace that Plato would be once and for all Nietzsche's chief adversary. In analysing the route of nietzschean thinking, we'll see that the philosopher, since his youth, and with the progressive aid of the physiological and psychological analysis as a tool, never confused Platonism with Plato as a man and legislator, receiving from him even the decisive influence to the "Great Politics" project. Parallel to this, we'll have that, despite considering himself as the sole critical heir of the Greek philosopher, reputed as a creator of new values, there are in fact some differences in the political projects of both philosophers, notably in the finishing period of nietzschean reflection, with the eternal recurrence of the same and the reading of the Manu's Code of Law.
\end{abstract}

Keywords: Nietzsche - Plato - politics - critical reception - Great Politics - Manu's Code of Law

\title{
referências bibliográficas
}

NIETZSCHE, F. Oeuvres philosophiques completes, Gallimard, 1968-1997. . Sämtliche Briefe. Kritische Studienausgabe. München DTV: Walter de Gruyter, 1986, 8v.

38 Carta de 16 de novembro de 1887.

146 | cadernos Nietzsche 32, 2013 
Os legisladores do futuro. A afinidade dos projetos políticos de Platão e de Nietzsche . Correspondance. Paris: Gallimard, 1986, $2 \mathrm{t}$.

. Lettres à Peter Gast, trad. Louise Servicen, rééd. Christian Bourgeois, 1986. . Le gai savoir. Trad. Patrick Wotling. Paris: Garnier-Flammarion, 1997. . Introduction à l'étude des dialogues de Platon. Trad. Olivier Sedeyn. Paris: Éditon de l'éclat, 1991. Além do bem e do mal. Trad. Paulo César Souza. São Paulo: Cia das Letras, 1996.

. Humano, demasiado humano I. Trad. Paulo César Souza. São Paulo: Cia das Letras, 2000.

. A gaia ciência. Trad. Paulo César Souza. São Paulo: Cia das Letras, 2001.

PLATÃO. La République. Trad. P. Pachet. Paris: Gallimard, 1993.

Artigo recebido em 18/10/2012.

Artigo aceito para publicação em 20/11/2012. 